\title{
PREDICTING THE DISTRIBUTION OF THE INVASIVE SPECIES HYPTIS SUAVEOLENS IN NIGERIA
}

\author{
OYINADE ADEROJU DAVID ${ }^{1, *}$, GBENGA FESTUS AKOMOLAFE ${ }^{2}$, \\ KENNETH CHIDINMA ONWUSIRI ${ }^{3}$, \\ and GIFT OLUWATODIMU FABOLUDE 4
}

\author{
${ }^{1}$ Department of Plant Science and Biotechnology, Faculty of Science, Federal University Oye-Ekiti, Oye-Ekiti, Nigeria \\ ${ }^{2}$ Department of Botany, Federal University of Lafia, Nasarawa State, Nigeria \\ ${ }^{3}$ National Environmental Standards and Regulations Enforcement Agency (NESREA), Akwa-Ibom State Field office, Uyo, Nigeria \\ ${ }^{4}$ Department of Environmental Management and Toxicology, University of Benin, Benin, Nigeria \\ * Corresponding author: oyinade.dedeke@fuoye.edu.ng
}

\section{ABSTRACT}

Hyptis suaveolens is an exotic plant that has become established in Nigeria because it is grows vigorously and produces allelochemicals that adversely affect the growth of adjacent plants. In this study, we predict the distribution of Hyptis suaveolens in Nigeria using a Maximum Entropy modelling approach. Pearson correlations were used to select five bioclimatic variables to which type of soil and altitude were added to give a total of seven environmental variables that were then included in the MaxEnt model. This model predicts that Hyptis suaveolens can colonize $25 \%, 45 \%$ and $25 \%$ of the total land area in FCT, Nasarawa and the River States in Nigeria. In addition, Hyptis suaveolens in Nigeria grows mainly in sandy clay and sandy loam soils. Bioclimatic conditions most suitable for this species include temperatures between $26-30^{\circ} \mathrm{C}$, 9-10 hour photoperiod, low altitudes of around $200-800 \mathrm{~m}$ and rainfall within the range of $200-800 \mathrm{~mm}$. The MaxEnt model indicates that Hyptis suaveolens is currently a threat to the survival of native species of plants in the North Central part of Nigeria. The MaxEnt model further reveals that because of its high adaptability and tolerance of changes in abiotic factors, Hyptis suaveolens is likely to invade a new environment, the humid forest zone in Nigeria. As this species can become very abundant, we recommend that its spread is monitored and controlled, particularly in areas of high suitability.

Keywords: climatic factors; Hyptis suaveolens; MaxEnt model; Nigeria; invasion

\section{Introduction}

Biological invasions are seen as threats to plant biodiversity, as they can alter the vegetation and change habitats (Mack and D'Antonio 1998; Mack et al. 2000) and thus reduce diversity (Meiners et al. 2001). In addition, invasion can reduce species richness through interspecific competition (D’Antonio et al. 1998; Christian and Wilson 1999; Parker et al. 1999; Meiners et al. 2001). Invasive species usually compete with native plants, which eventually affects species evenness in communities (Sharma et al. 2009). Invasive alien species (IAS) affect native plants by competing for space and nutrients (Borokini 2011). Global invasive species database documents 6 species of grass, 6 shrubs, 8 trees, 8 herbaceous plants and 2 sedges occurring in Nigeria whereas, Borokini (2011) identifies 25 IASs in Nigeria, but does not include Hyptis sauvolens. In total, 487 protected sites in the world are under threat and protected areas in 106 countries are seriously under siege from IASs (De Poorter et al. 2007).

Hyptis suaveolens (L.) is among the most damaging of the invasive species invading a wide range of ecosystems in tropical and sub-tropical regions in the world (Sarmiento 1984; Afolayan 1993; Padalia et al. 2014). Hyptis suaveolens is an annual herbaceous plant belonging to the family Lamiaceae. It thrives in high rainfall warm tropical and sub-tropical regions. Also, it can survive in semi-arid areas, where it propagates by means of seed. Optimal growth of $H$. suaveolens is recorded be- tween 25 to $30{ }^{\circ} \mathrm{C}$ and it can germinate at temperatures between 10 to $40{ }^{\circ} \mathrm{C}$ (Felippe et al. 1983). In savannah, dominance of $H$. suaveolens is mainly associated with land from which humans have removed the vegetation by burning or over-grazing (Wulff 1987). It grows rapidly in cultivated fields and disturbed sites, especially where mechanized farming and intense cattle grazing are practised (Holmes 1969). This plant also grows along roadsides and watercourses. It has a strong tendency to grow abundantly in open woodlands and rangelands. It produces a dense growth and releases allelochemicals, which inhibit the germination of the seeds and growth of indigenous species.

Moreover, prolific seed production (Raizada 2006), easy dispersal (Parsons and Cuthburtson 2000) and phenotypic plasticity means this species can colonize many habitats (Sharma and Raghubanshi 2009). The release of unpleasant scent makes it unpalatable for livestock and partly accounts for its abundance over a broad ecological range. The proliferation of Hyptis is characterized by some morphological features that enable it to grow in poor quality soils, such as the small size of its seed, seed dimorphism, auto gamic and allogamic reproduction and vigorous growth from perennating rootstocks (Raizada 2006).

Climate is an important factor affecting plant distribution (Catford et al. 2009; González-Moreno et al. 2013). Global climate change has focused attention on the prediction of plant distribution and likely future trends 


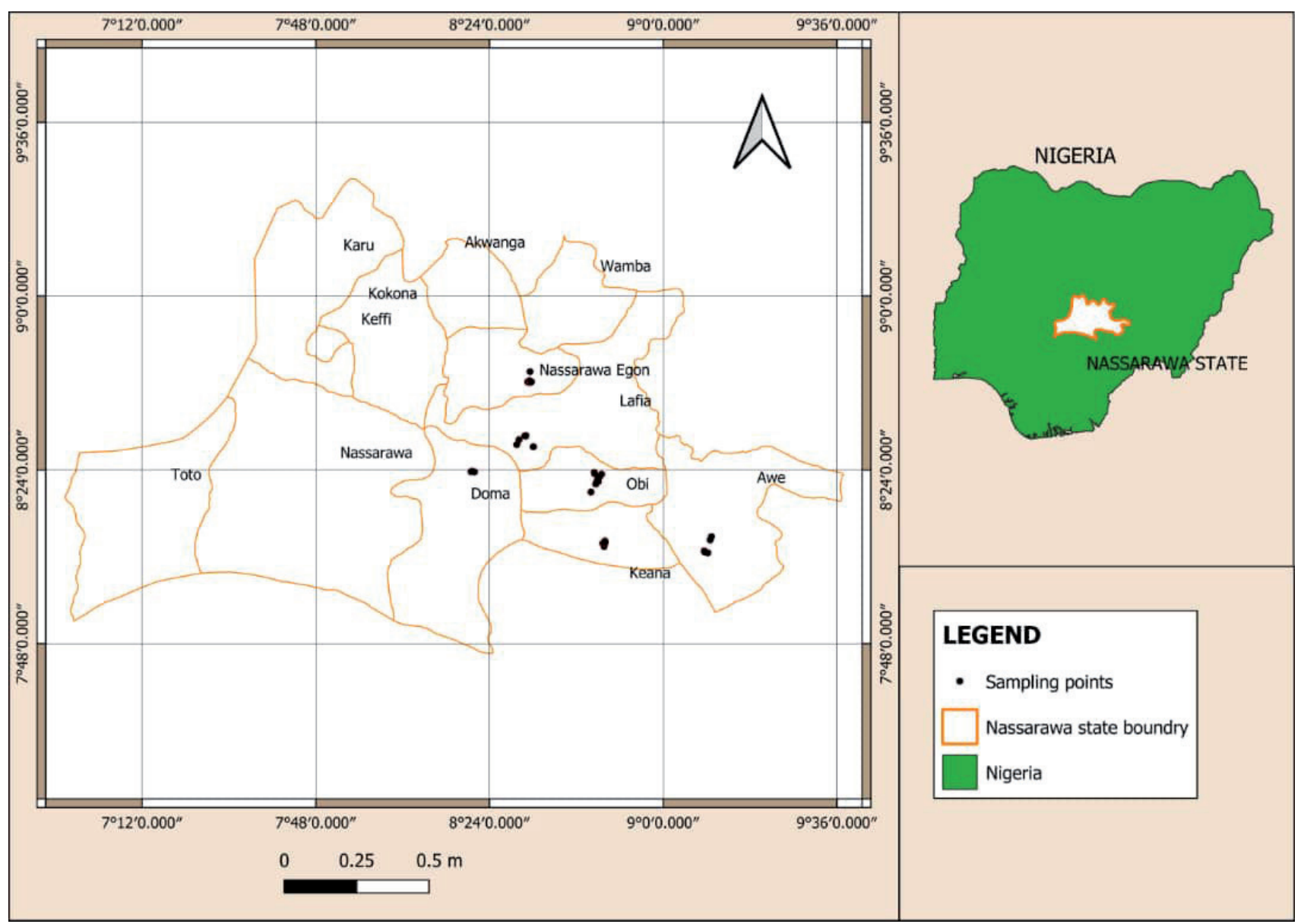

Fig. 1 The sites where Hyptis suaveolens occurred in Nasarawa State, Nigeria.

(González-Moreno et al. 2013). The MaxEnt model helps us understand the highly complex relationships between the occurrence of species and their environments (Busby 1991; Phillips et al. 2006). It compares their coordinated geographical data in terms of climate factors in order to predict their probable distributions (Guillera-Arroita et al. 2014; Shabani et al. 2018). Predicting the potential distribution of $H$. suaveolens will facilitate the development of the methods needed to curtail its adverse effect on native species. Currently, the potential distribution of Hyptis suaveolens in Nigeria is unknown. This study, therefore, aims to predict the potential distribution of Hyptis suaveolens in Nigeria using a Maximum Entropy modelling approach.

\section{Material and Methods}

\section{Study area}

This study was carried out in Nasarawa state, which is situated between latitude $8^{\circ} 25^{\prime} 40^{\prime \prime} \mathrm{N}$ and longitude $8^{\circ} 39^{\prime} 19^{\prime \prime} \mathrm{E}$. The sampling was carried out in 6 local government areas (LGAs) including Awe, Keana, Obi, Eggon and Lafia. The spatial data for this plant at each site was collected using a quadrant of size $20 \times 20 \mathrm{~m}$. Hyptis suaveolens was sampled at 76 different locations for which the latitude, longitude and altitude were determined using a GPS device (Fig. 1).

\section{Environmental data}

Environmental variables used in the model were downloaded from WorldClim (worldclim.org). The bioclimatic data were obtained from monthly temperature and rainfall values and consist of 19 variables, which are listed in Table 1. The spatial resolution of these variables is 2.5 arc minutes. Digital Altitude Model (DEM) data were downloaded from USGS Earth Explorer. The soil type is a categorical variable and was obtained from data. mendeley.com (Nkwunonwo et al. 2020). ArcGIS 10.2.1 software was used for all the conversions and analyses used for the MaxEnt modelling.

It is likely that the bioclimatic variables are highly correlated with one another, which can affect the performance of the model. Therefore, a multicollinearity test was conducted, according to Pradhan (2016), using ENM Tools and based on Pearson correlation coefficients (r). The VIFs (Variance Inflation Factor), which were obtained using the formula $1 /\left(1-r^{2}\right)$, were analysed using Excel 2015 software. Errors due to multicollinearity were screened out using the standardized values of $\mathrm{r}>0.8, \mathrm{r}^{2}>$ 0.8 and VIF value $>10$, but values of $\mathrm{r}>0.8$ and VIF $>10$ were also considered following Pradhan (2016). The 
Multicollinearity test resulted in five bioclimatic variables being selected (Table 2).

Table 1 Description of bioclimatic variable prior to the Multicollinearity test.

\begin{tabular}{|l|l|}
\hline Code & Description \\
\hline BIO1 & Annual Mean Temperature \\
\hline BIO2 & $\begin{array}{l}\text { Mean Diurnal variation in temperature (Mean of monthly } \\
\text { (max temp - min temp)) }\end{array}$ \\
\hline BIO3 & Isothermality (BIO2/BIO7) $(\times 100)$ \\
\hline BIO4 & Seasonal range in temperature (standard deviation $\times 100)$ \\
\hline BIO5 & Max Temperature in Warmest Month \\
\hline BIO6 & Min Temperature in Coldest Month \\
\hline BIO7 & Annual range in temperature (BIO5-BIO6) \\
\hline BIO8 & Mean Temperature in Wettest Quarter \\
\hline BIO9 & Mean Temperature in Driest Quarter \\
\hline BIO10 & Mean Temperature in Warmest Quarter \\
\hline BIO11 & Mean Temperature in Coldest Quarter \\
\hline BIO12 & Annual Precipitation \\
\hline BIO13 & Precipitation in Wettest Month \\
\hline BIO14 & Precipitation in Driest Month \\
\hline BIO15 & Seasonal variation in Precipitation (Coefficient of Variation) \\
\hline BIO16 & Precipitation in Wettest Quarter \\
\hline BIO17 & Precipitation in Driest Quarter \\
\hline BIO18 & Precipitation in Warmest Quarter \\
\hline BIO19 & Precipitation in Coldest Quarter \\
\hline
\end{tabular}

Table 2 Bioclimatic variables remaining after the Multicollinearity test.

\begin{tabular}{|l|l|}
\hline Code & Description \\
\hline BIO1 & Annual Mean Temperature \\
\hline BIO2 & $\begin{array}{l}\text { Mean Diurnal variation in temperature (Mean of monthly } \\
(\text { max temp - min temp) }\end{array}$ \\
\hline BIO3 & Isothermality $(\mathrm{BIO} / \mathrm{BIO})(\times 100)$ \\
\hline BIO8 & Mean Temperature in Wettest Quarter \\
\hline BIO19 & Precipitation in Coldest Quarter \\
\hline
\end{tabular}

The Soil type and DEM were included in a raster and then converted to an ASCII file with the same extent and cell size using ArcGIS 10.2.1. The soil types were categorized based on their texture. The ArcGIS 10.2.1 was used to produce a map of the locations of the sites sampled, along with the density, soil type and kriging interpolation.

\section{Modelling}

MaxEnt (Maximum entropy) version 3.4.1 was used to determine the potential distribution of $H$. suaveolens in Nigeria. Of the various models, the predictions of the MaxEnt model are often the most precise, possibly because they are based on applications, such as domain, and bioclimatic and logistic regressions (Hijmans and Graham 2006; Phillips and Dudik 2008). MaxEnt evaluates the habitat suitability of a targeted species by analysing the maximum entropy of the environmental variables of species occurrence data. (Phillips et al. 2006). Even when there are data for only a few occurrences, this model still gives an accurate prediction. The MaxEnt generated continuous outputs with ten replicates using subsample replication and the averages of the replicates are presented. A maximum of 1000 iterations was allowed.

\section{Model evaluation}

The curves of the species responses to predictors predicted by the model were analysed to determine the patterns. Jackknife test was used to assess the contributions of individual variables to the MaxEnt predictions. In the Jackknife test, the training loss/gains for all the variables, without the specific variable, and with each variable in isolation, were used to evaluate the model. This was done for all the predictor environmental variables used in the model (Padalia et al. 2014) Receiver operating characteristic (ROC) area under curve (AUC) method was used to determine the performances of the MaxEnt model (Shabani et al. 2018). The AUC provides a single measurement of model performance, independently of any particular choice of threshold. The value of the AUC ranges from 0 to 1 , indicating the model performance. This method is widely used for comparing the performances of species distribution models (Padalia et al. 2014).

\section{Spatial distribution}

The occurrence data for $H$. suaveolens was converted to Shp (Shapefile) and used to map the density of occurrence on-site and kriging interpolation generated for density.

\section{Results}

The soils at locations where Hyptis suaveolens was recoded in Nasarawa state, Nigeria, varied from sandy clay-to-clay loam (Fig. 2). Considering the density of occurrence of $H$. suaveolens, the results show that the density of this plant ranged from $9-11$ plants $/ \mathrm{m}^{2}$ at the six areas studied (Fig. 3). However, the highest density occurred in Awe LGA and lowest in some parts of Lafia, Doma, Obi and Keana (Fig. 4). The AUC test ranged from 0.972-0.991 and Training AUC ranged from 0.9850.992 (Fig. 5). The average AUC for the replicate runs is 0.982 and the standard deviation is 0.007 , which indicate that MaxEnt prediction of the distribution of Hyptis suaveolens in Nigeria is accurate (Fig. 5). The Maxent model revealed that the omission rate of the training and test portions of the data is zero. This indicates that this model correctly predicts the presence $H$. suaveolens in the areas that are $100 \%$ suitable for its invasion. The average AUC of the ROC for the training and test data of the MaxEnt model is 0.988 and 0.982 , respectively, whereas that of random prediction is 0.5 . This reveals that this model accurately discriminates between the suitable and unsuitable habitats for H. suaveolens. 


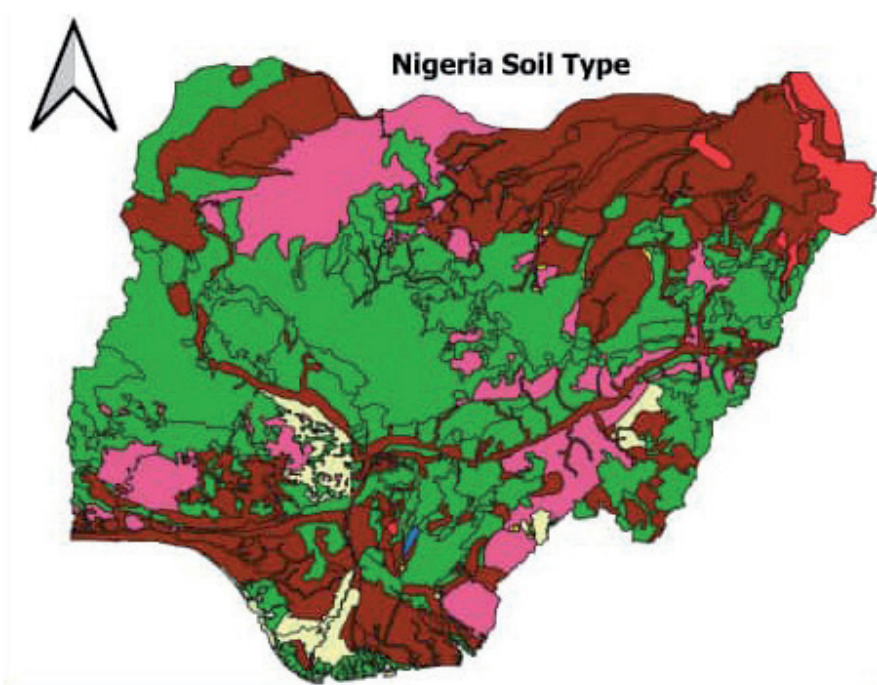

Nassarawa State Soil Type

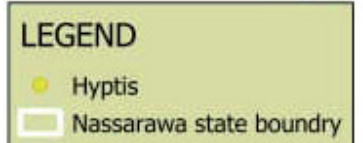

Soil Types

$\square$ Clay Loam

$\square$ Concretionary Clay

$\square$ Loamy fine sand

$\square$ Sandy

$\square$ Sandy Clay

Sandy Loam

Silty Clay

$\square$ Silty Loam

Fig. 2 The distribution of the different types of soil at localities where H. suaveolens occurred in the area studied.

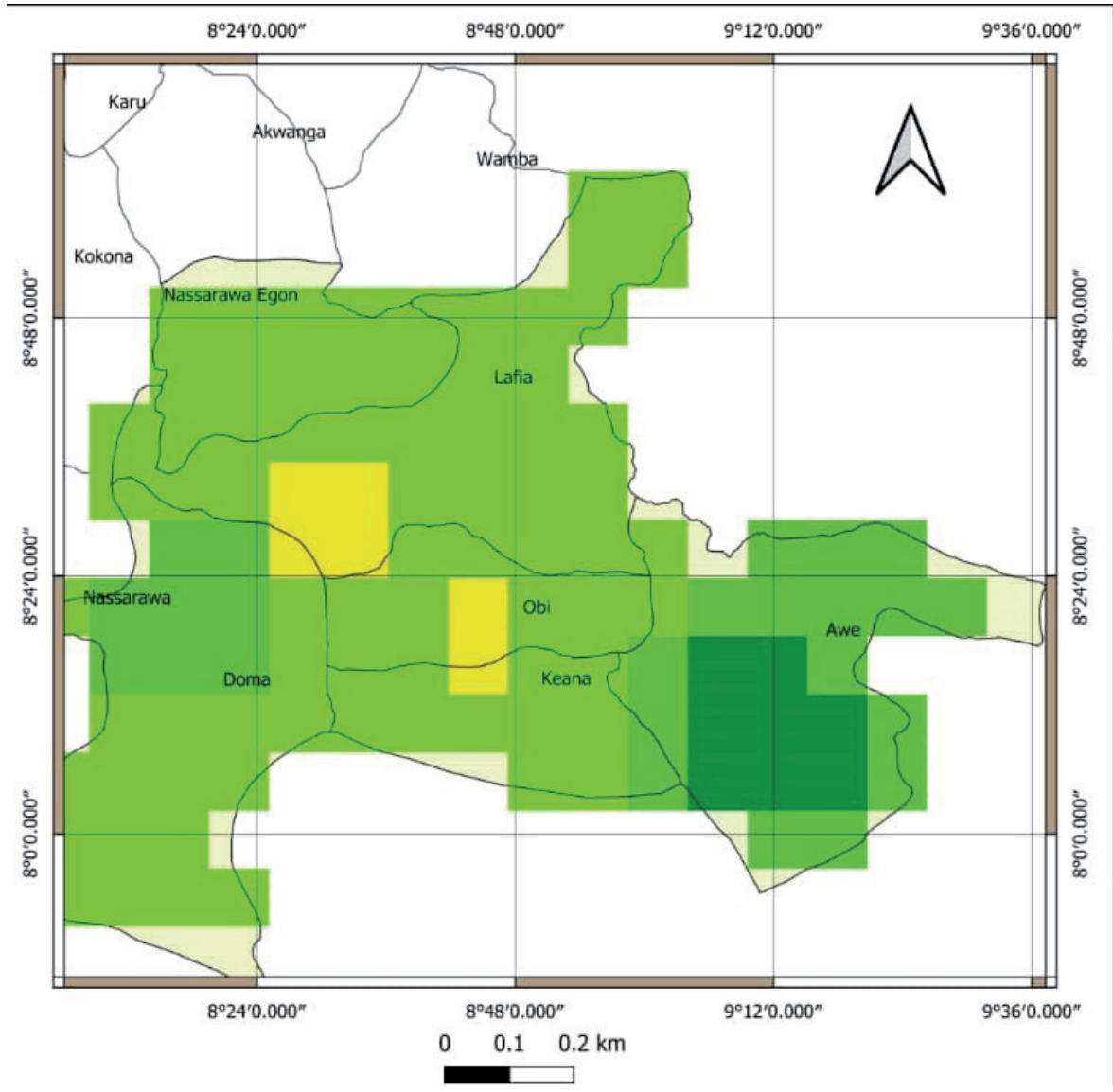

\begin{tabular}{|c|}
\hline $\begin{array}{l}\text { LEGEND } \\
\text { Occurrence } \\
\text { density }\end{array}$ \\
$<3$ \\
$3-5$ \\
$6-8$ \\
$6-11$ \\
$9-11$ \\
$>11$ \\
$\square$ No data \\
\hline
\end{tabular}

Fig. 3 The density of occurrence of H. suaveolens in particular areas in Nasarawa State, Nigeria. 


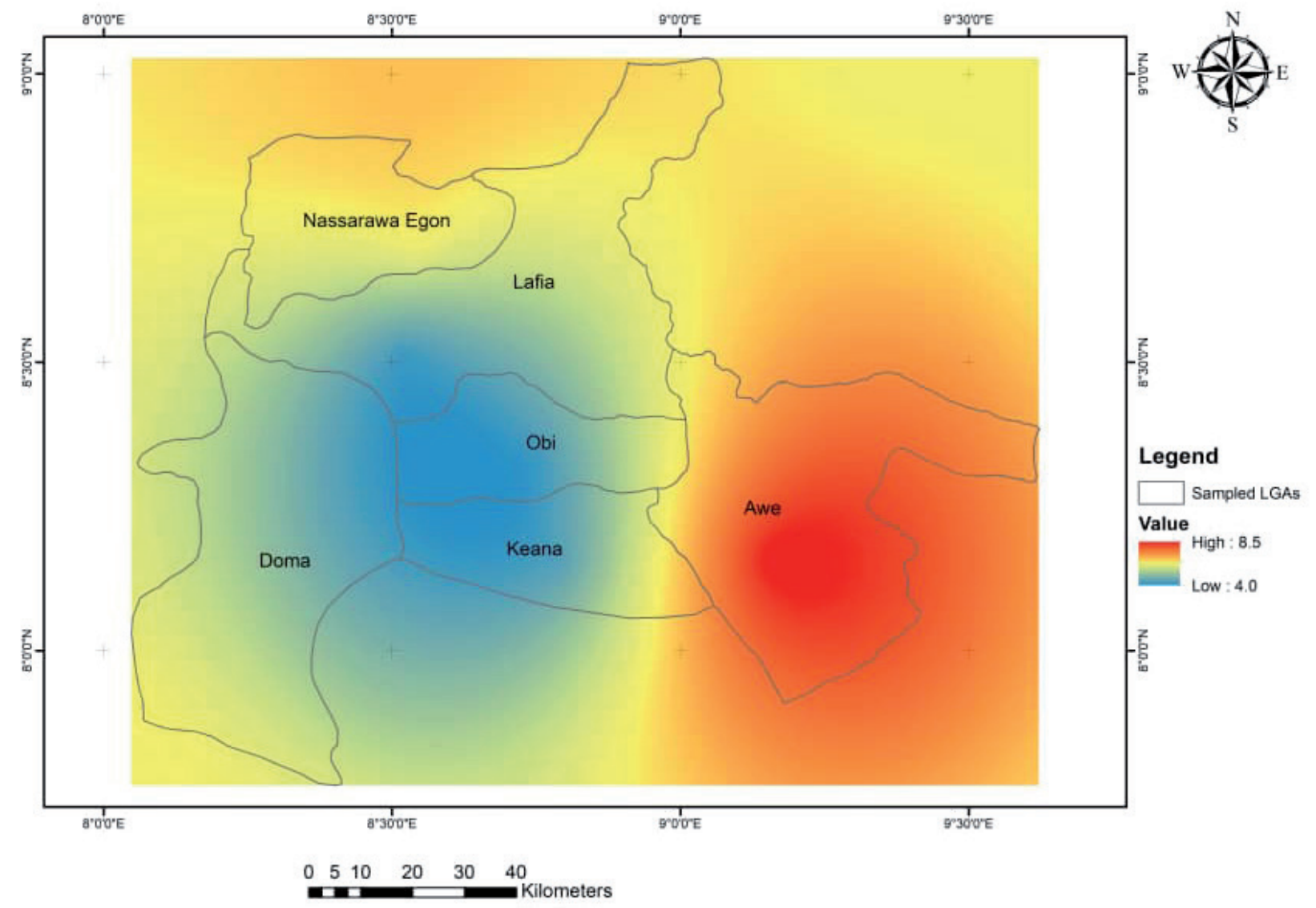

Fig. 4 Kringing Interpolation of the density of occurrence.

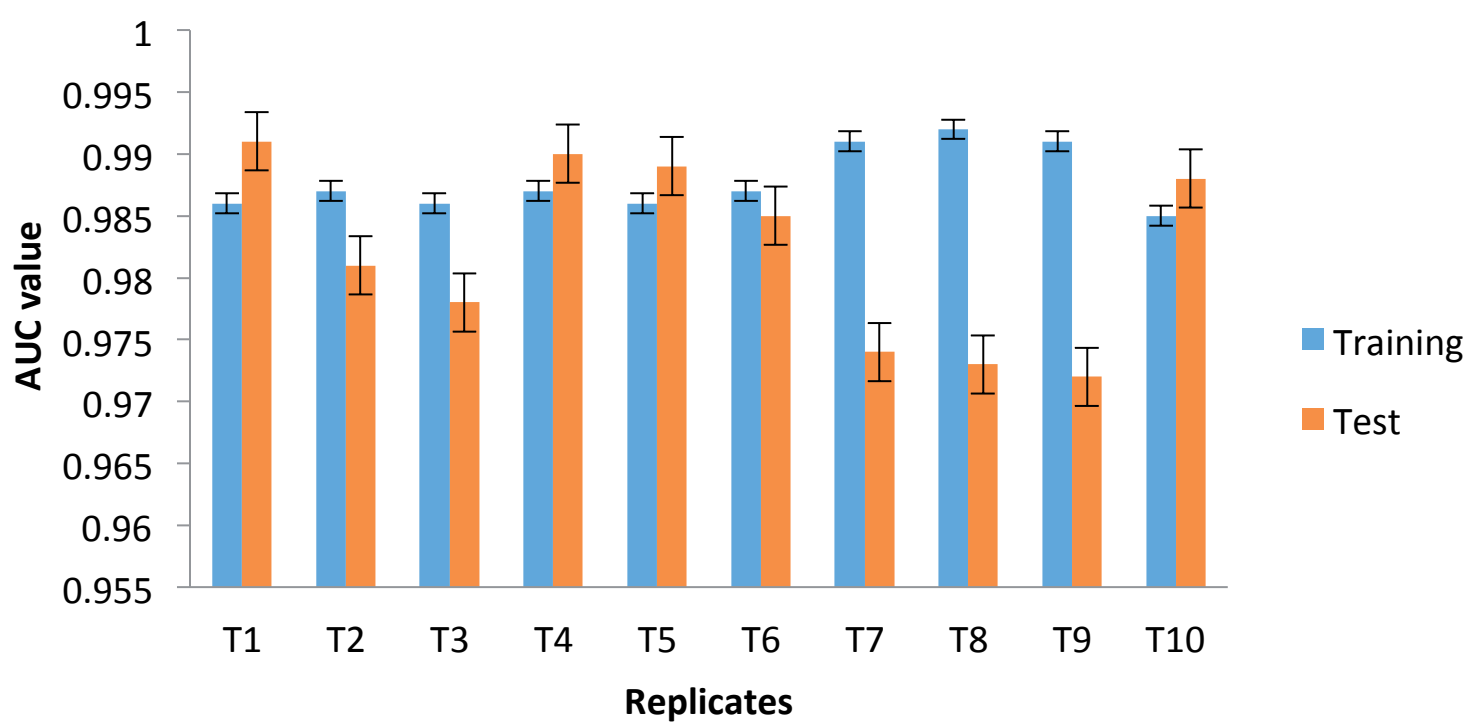

Fig. 5 Evaluation of the Test and training AUC values of the ten-cross-model validations.

The model can be used to predict with a probability of between $0.62-1.00$ those areas in Nigeria that are suitable for $H$. suaveolens. The nine areas predicted to be most suitable for $H$. suaveolens in Nigeria include Abuja (FCT), Nasarawa, Plateau, Taraba, Adamawa, Cross River, Bayelsa Rivers and Abia (Fig. 6). Of the nine states, three are in the North Central, 2 in the North East, 3 in the South-South and 1 in the southeast zone (Table 3 ). All the other states in Nigeria are predicted to be less suitable for this plant. It is predicted that the highest percentage of the land (47.5\%) likely to be invaded by H. suaveolens in Nigeria is in Nasarawa State, followed by Rivers and Abuja, with 25\% (Table 3). The least affected State is Adamawa for which the prediction is $1.49 \%$. The Jackknife analysis used to identify the contributions of each of the predictor abiotic variables revealed that isothermality on its own was not important (Fig. 7). Soil type was the only variable that was important on its own. The effects of all 
Table 3 Areas of land predicted to be affected by H. suaveolens in Nigeria.

\begin{tabular}{|c|l|c|c|c|c|}
\hline S/N & Name of State & Geopolitical Zone & Total Area $\mathbf{( k m}^{\mathbf{2})}$ & $\begin{array}{c}\text { Area predicted } \\
\left.\text { to be affected } \mathbf{( k m}^{\mathbf{2}}\right)\end{array}$ & $\begin{array}{c}\text { Percentage of the area } \\
\text { affected } \mathbf{\%})\end{array}$ \\
\hline 1 & Abia & South East & 4723.46 & 429.41 & 9.09 \\
\hline 2 & Abuja (FCT) & North Central & 7353.15 & 1838.29 & 25 \\
\hline 3 & Adamawa & North East & 34323.63 & 512.29 & 1.49 \\
\hline 4 & Bayelsa & South-South & 10173.35 & 678.22 & 6.67 \\
\hline 5 & Cross River & South-South & 21153.35 & 515.94 & 2.44 \\
\hline 6 & Nasarawa & North Central & 26313.58 & 12500 & 47.5 \\
\hline 7 & Plateau & North Central & 27562.53 & 1968.75 & 7.14 \\
\hline 8 & Rivers & South-South & 9100.54 & 2275.14 & 25 \\
\hline 9 & Taraba & North East & 60115.8 & 1134.3 & \\
\hline
\end{tabular}

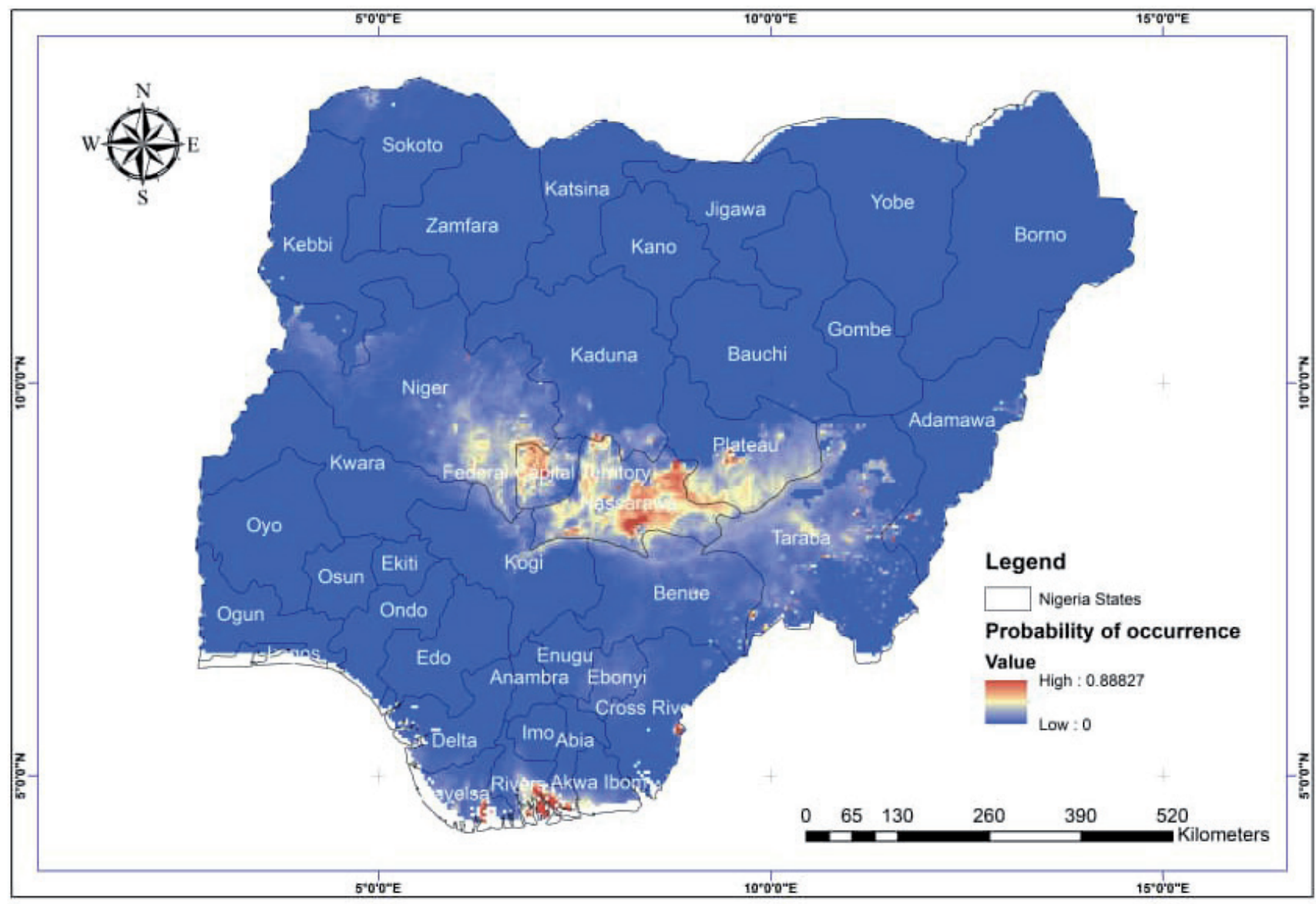

Fig. 6 Map showing the predicted probability of occurrence of H. suaveolens in Nigeria.

Jacknife of regularized training gain for $\mathrm{H}_{\mathrm{y}}$ ptis suaveolens

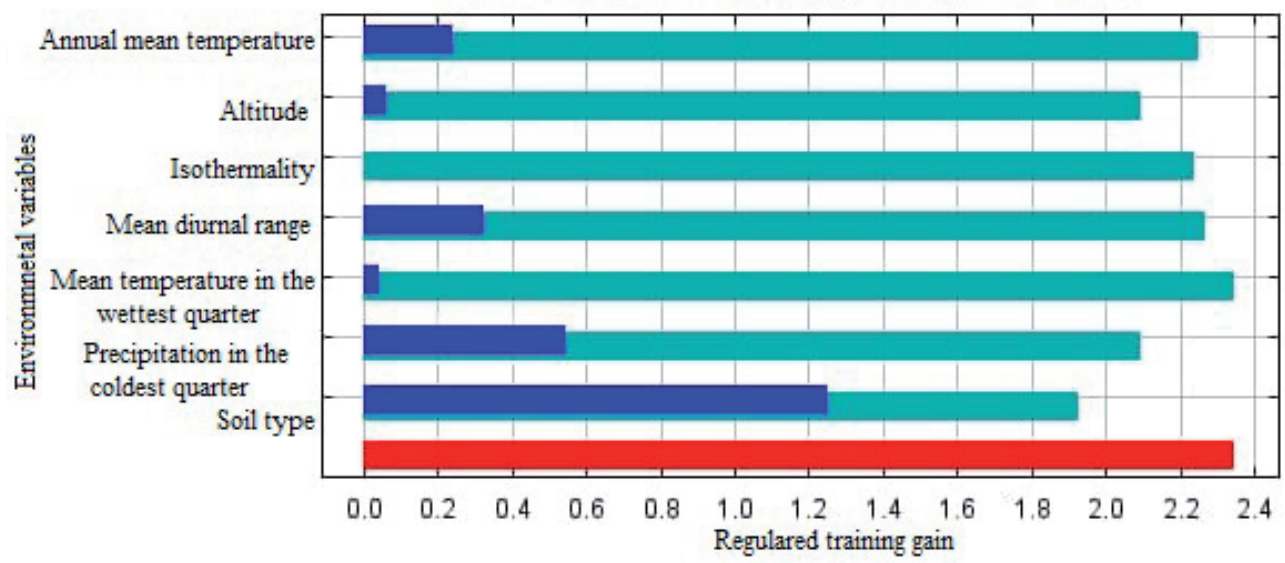

Without variable $=$

With only variable

With all variables

Fig. 7 Jackknife plots of the training data. 

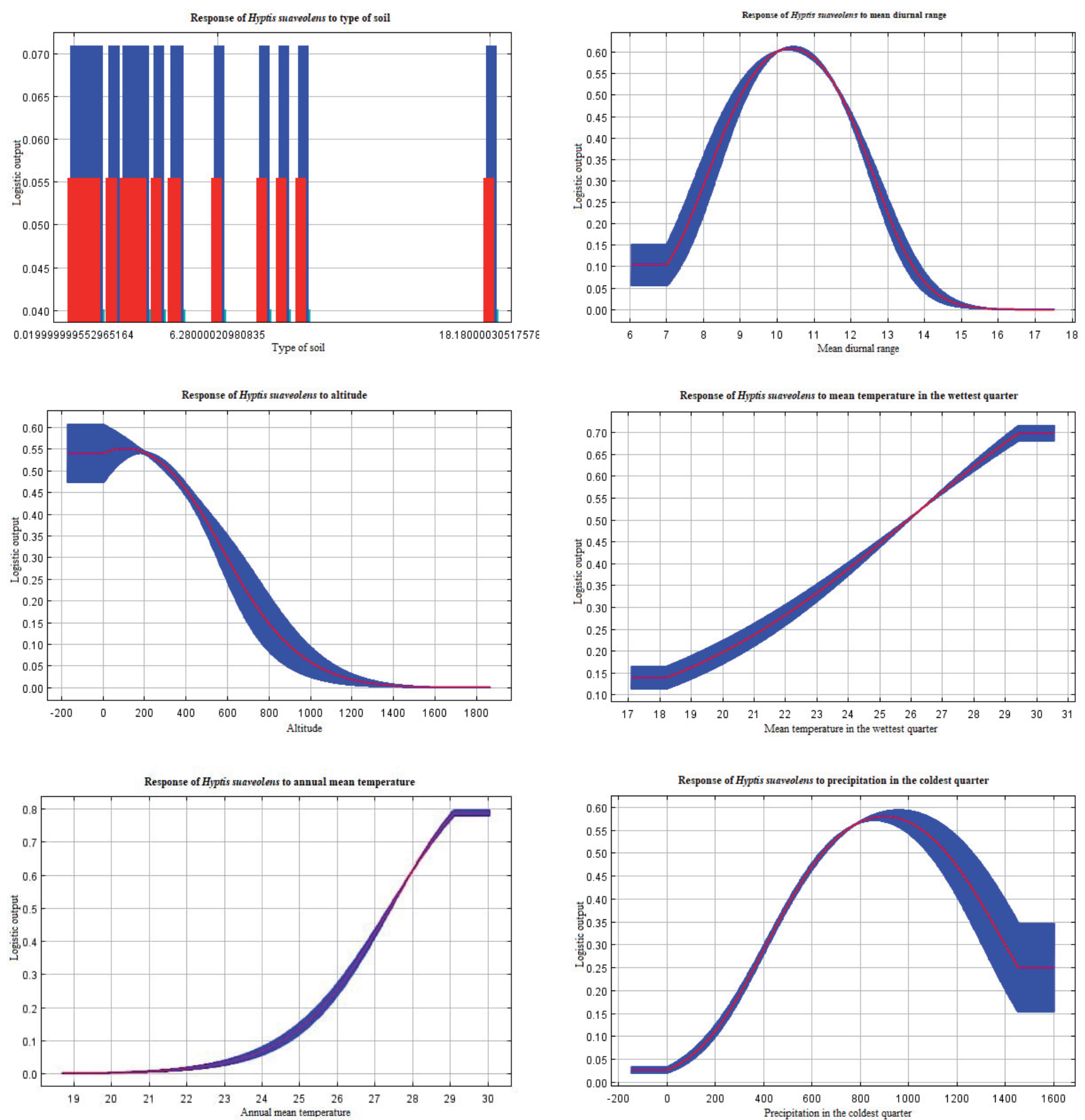

Fig. 8 The responses of $H$. suaveolens to (A) type of soil, (B) mean diurnal variation in temperature, (C) altitude, (D) mean temperature in the wettest quarter, $(E)$ annual mean temperature and (F) precipitation in the coldest quarter. Red curves = mean response and blue margins = \pm 1 SD based on 10 replicates.

the variables based on their respective contributions are depicted in Figure 7. These are regarded as the most important predictors of the areas likely to be invaded by $H$. suaveolens in Nigeria. Their individual percentage contributions to the prediction are: soil type $(52.08 \%)$, mean diurnal variation in temperature $(12.5 \%)$, precipitation in the coldest quarter $(22.08 \%)$, annual mean temperature $(9.5 \%)$, mean temperature in the wettest quarter $(2.08 \%)$ and altitude $(3.7 \%)$. Probability of $H$. suaveolens occurring at high altitudes (above $1000 \mathrm{~m}$ ) was $<0.05$ and for those occurring between $200-800 \mathrm{~m}$ ranged between $0.15-0.5$. The probability of its occurrence $(>0.5)$ increased with increase in the mean temperature in the wettest quarter $\left(26^{\circ} \mathrm{C}\right.$ to $\left.30^{\circ} \mathrm{C}\right)$. Favourable precipitation in the coldest quarter ranged from $200-800 \mathrm{~m}$. The probability of an area being invaded by $\mathrm{H}$. suaveolens $(>0.5)$ increases when the mean diurnal variation in temperature is $>0.5$, photoperiod less than 10 hours and the isothermal is $50-60 \mathrm{~J} \mathrm{~K}^{-1}$ (Fig. 8).

\section{Discussion}

Hyptis suaveolens in areas already invaded is abundant and spreading rapidly, resulting in the homogeneity of floras, reduced biodiversity and a reduction in the ecolog- 
ical integrity of the native habitats and ecosystems functioning (Hulme et al. 2003; Borokini and Babalola 2012). It has caused a $46-52 \%$ decrease in species evenness in the periurban ecosystems in Chandigarh, north-western India (Sharma et al. 2017). There are invasive potential hotspots of Hyptis suaveolens in Abia, Adamawa, Bayelsa, Cross River, Nasarawa, Plateau, Rivers, Taraba and Rivers States, especially between latitude $8^{\circ} 52^{\prime} \mathrm{N}$ and $12^{\circ} 07^{\prime} \mathrm{E}$ in areas with derived savannah, which have suitable climatic conditions. Derived savannah is disturbed forest, which was cleared mechanically, or by burning or manual hand-weeding for agricultural purposes, which - when abandoned - are colonized by grasses. Recurrent fires and overgrazing are also frequent in this ecological zone. Hyptis suaveolens is described as an invader of grassland. This weed grows vigorously in agricultural fields, rangelands, pasture, floodplains, open woodlands, roadsides and disturbed areas (Raizada 2006; Padalia et al. 2014). It is predicted that the Federal Capital Territory (FCT) and Rivers State has suitable eco-climatic conditions and is very likely to be invaded by this plant, which could seriously reduce the biodiversity in this humid forest zone. This is because $H$. suaveolens thrives in a wide range of climatic conditions. The ecological amplitude and seed dimorphism of this species enables it to germinate over a wide range of temperatures, which results in year-round seed germination (Raizada 2006). The seeds of H. suaveolens are capable of germinating at temperatures between $10{ }^{\circ} \mathrm{C}$ and $40{ }^{\circ} \mathrm{C}$, but $25-30{ }^{\circ} \mathrm{C}$ seems to be the optimum for growth (Felippe et al. 1983).

Importantly, this plant prefers sandy clay and sandy loam soils, which further broadens the range conditions in which it can survive. This may enable it to thrive in new environments such as Benue, Kogi, Niger, Kaduna and Bauchi States, in the future. Similarly, H. suaveolens thrives in sandy soil with a high $\mathrm{pH}$, low fertility and is well-drained (Aboh et al. 2017), which with climate change could result in it invading new habitats (Padalia et al. 2015).

The results also indicate that the mean temperature in the wettest quarter, annual mean temperature, altitude, diurnal variation in temperature and precipitation in the coldest quarter were the most important bioclimatic factors determining the survival and growth of H. suaveolens in Nigeria. Low temperature and low moisture environments limit its invasive potential worldwide (Padalia et al. 2014). It is well known that other climatic factors, such as moisture balance and extreme temperatures, determine plant distribution (Stephenson 1990; Widrlechner et al. 2012; Zhang et al. 2020). Several studies report the effect of moisture and extreme temperatures on the physiological characteristics of plants, such as growth, yield, flowering and tolerance (Tandazo-Yung et al. 2017; Song et al. 2018).

Type of soil, diurnal variation in temperature, altitude, precipitation and temperature are significant factors determining the distribution of the targeted plant. In addition, areas with lower mean diurnal variation in temperature at low altitudes are more prone to being invaded. High abundances of $H$. suaveolens in Nigeria occur mainly at altitudes between $200-800 \mathrm{~m}$, where the temperature is between $26^{\circ} \mathrm{C}$ and $30^{\circ} \mathrm{C}$, rainfall between 200-800 $\mathrm{mm}$ with a photoperiod of 9-10 hours. Probability of occurrence is very low at altitudes above $1500 \mathrm{~m}$, where conditions are too cold for this species (Padalia et al. 2014). Its occurs at an altitude $\sim 1560 \mathrm{~m}$ in its native range in Venezuela, (GBIF 2013) and has invaded the central highlands at an altitude $\sim 850 \mathrm{~m}$ in India (Padalia et al. 2014). It prefers wet and warmer environments, as it is an annual herbaceous plant originating from the tropics (Padalia et al. 2015). It is a short-day plant with optimum growth at temperatures ranging between 25 and $30^{\circ} \mathrm{C}$ (Raizada 2006; Barbosa et al. 2013).

In this study, the MaxEnt model was used to predict the distribution of $H$. suaveolens in Nigeria. This revealed that abiotic factors such as type of soil, mean temperature in the warmest quarter, precipitation in the coldest quarter, altitude and diurnal variation in temperature are the most important factors determining its occurrence and distribution in Nigeria. Among these factors, type of soil was the most important. The model predicted a high occurrence of $H$. suaveolens in derived savannah in Nigeria (FCT, Nasarawa, and Plateau States) and because of its broad ecological tolerance a future occurrence in humid forest areas (Rivers and Cross Rivers States) in Nigeria, which would be a major threat to the native vegetation in humid forest. This invasion seriously threatens the survival of native plants in the most suitable areas, therefore, there is an urgent need to stop the spread and control the abundance of $H$. suaveolens in Nigeria.

\section{Acknowledgements}

The authors appreciate the support of Mr Okoh Alu in the collection of the data.

\section{REFERENCES}

Aboh, BA, Teko O, Djikpo R, Oumorou M, Mensah GA, Sinsin B (2017) Topographic and edaphic factors determining Chromolena odorata and Hyptis suaveolens invasion of grassland in the Guineo-Congolian/Sudanian transition zone (Benin). J Appl Biosci 111: 10916-10924.

Afolayan AJ (1993) Germination and growth features of seed of different sizes in Hyptis suaveolens (L.) Poit. Range Manag Agrofor 14: 139-145.

Barbosa LCA, Martins FT, Teixeira RR, Polo M, Montanari RM (2013) Chemical variability and biological activities of volatile oils from Hyptis suaveolens (L.) Poit. Agric Conspec Sci 78: 10.

Borokini TI (2011) Invasive alien plant species in Nigeria and their effects on biodiversity conservation. Trop Conserv Sci 4: 103-110.

Borokini TI, Babalola FD (2012) Management of invasive plant species in Nigeria through economic exploitation: lessons from other countries. Manag Biol Invasions 3: 45-55. 
Busby, JR (1991) BIOCLIM-a bioclimate analysis and prediction system. In: Margules CR, Austin MP (eds) Nature conservation: cost effective biological surveys and data analysis. CSIRO Melbourne, pp 64-68.

Catford JA, Jansson R, Nilsson C (2009) Reducing redundancy in invasion ecology by integrating hypotheses into a single theoretical framework. Divers Distrib 15: 22-40.

Christian JM, Wilson SD (1999) Long-term ecosystem impacts of an introduced grass in the northern Great Plains. Ecology 80: 2397-2407.

D’Antonio CM, Hughes RF, Mack M, Hitchcock D, Vitousek PM (1998) Response of native species to the removal of non-native grasses in a Hawaiian woodland. J Veg Sci 9: 699-712.

De Poorter M, Pagas S, Ullah MI (2007) Invasive alien species and protected areas: A scoping report. World Bank, IUCN, ISSG, GIS pp 93.

Felippe GM, Polo M, Cardosa VJM, Figeiredo-Ribeiro RCL (1983) Germinacao da unidade de dispersao de erva invasora Hyptis suaveolens. An Sem Reg Ecol 3: 245-261.

Global Biodiversity Information Facility (GBIF) (2013) (http:// data.gbif.org/welcome.htm, accessed on 12 January, 2013).

González-Moreno P, Pino J, Carreras D, Basnou C, Fernández-Rebollar I, Vilà M (2013) Quantifying the landscape influence on plant invasions in Mediterranean coastal habitats. Landscape Ecol 28: 891-903.

Guillera-Arroita G, Lahoz-Monfort J, Elith J (2014) Maxent is not a presence-absence method: a comment on Thibaud et al. Methods Ecol Evol 5: 1192-1197.

Hijmans RJ, Graham CH (2006) The ability of climate envelope models to predict the effect of climate change on species distributions. Global Change Biol 12: 2272-2281.

Holmes JE (1969) Noxious weeds. Turnoff 4: 28-29.

Hulme PE (2003) Biological invasions: Winning the science battles but losing the conservation war? Oryx 37: 178-193.

Mack MC, D’Antonio CM (1998) Impacts of biological invasions on disturbance regimes. Trends Ecol Evol 13: 195-198.

Mack RN, Simberloff D, Lonsdale WM, Evans H, Clout M, Bazzaz, FA (2000) Biotic invasions: causes, epidemiology, global consequences, and control. Ecol Appl 10: 689-710.

Meiners SJ, Pickett STA, Cadenasso ML (2001) Effects of plant invasions on the species richness of abandoned agricultural land. Ecography 24: 633-644.

Nkwunonwo UC, Okeke FI, Ebinne ES, Chiemelu NE (2020) Free, open, quantitative and adaptable digital soil map data and database for Nigeria. Data in Brief 31: 105941.

Padalia H, Srivastava V, Kushwaha SPS (2014) Modeling potential invasion range of alien invasive species, Hyptis suaveolens (L.) Poit. in India: Comparison of MaxEnt and GARP. Ecol Inform 22: $36-43$.

Padalia H, Srivastava V, Kushwaha SPS (2015) How climate change might influence the potential distribution of weed, bushmint (Hyptis suaveolens). Environ Monit Assess 187: 210-214.

Parker IM, Simberloff D, Lonsdale WM, Goodell K, Wonham M, Kareiva PM, Williamson MH, Von Holle B, Moyle PB, Byers JE Goldwasser L (1999) Impact: toward a framework for understanding the ecological effects of invaders. Biol Invasion 1: 3-19.
Parsons WT, Cuthburtson EG (2000) Noxious weeds of Australia CSIRO publications, pp 490-491.

Phillips SJ, Anderson RP, Schapire RE (2006) Maximum entropy modeling of species geographic distributions. Ecol Model 190: 231-259.

Phillips SJ, Dudik M (2008) Modeling of species distributions with MaxEnt: new extensions and a comprehensive evaluation. Ecography 31: 161-175.

Pradhan P (2016) Strengthening MaxEnt modelling through screening of redundant explanatory Bioclimatic Variables with Variance Inflation Factor analysis. Researcher 8: 29-34.

Raizada P (2006) Ecological and vegetative characteristics of a potent invader, Hyptis suaveolens Poit. from India. Lyonia 11: $115-12$.

Raizada P (2006) Ecological and vegetative characteristics of a potent invader, Hyptis suaveolens Poit. from India. Lyonia 11: $115-12$.

Sarmiento G (1984) The ecology of neotropical savannas.Cambridge: Harvard University Press.

Shabani F, Kumar L, Ahmadi M (2018) Assessing accuracy methods of specie distribution models: AUC, specificity, sensitivity and the true skill statistic. Global J Human-Soc Sci (B) 18:7-18.

Sharma A, Batish DR, Singh HP, Jaryan V, Kohli RK (2017) The impact of invasive Hyptis suaveolens on the floristic composition of the periurban ecosystems of Chandigarh, northwestern India. Flora 233: 156-162.

Sharma GP, Raghubanshi AS (2009) Plastic responses to different habitat type contribute to Hyptis suaveolens Poit. invasiveness in the dry deciduous forest of India. AMBIO: J Human Environ 38: 342-344.

Sharma GP, Raizada P, Akhilesh S, Raghubanshi A (2009) Hyptis suaveolens: An emerging invader of Vindhyan plateau, India. Weed Biol Manag 9: 185-191.

Song S, Li FD, Lu YL, Khan K, Xue JF, Leng PF (2018) Spatio-temporal characteristics of the extreme climate events and their potential erects on crop yield in Ethiopia. J Resour Ecol 9: 290-301.

Stephenson NL (1990) Climatic control of vegetation distribution: The role of water balance. Am Nat 135: 649-670.

Tandazo-Yung JV, Ruiz-González MX, Rojas JR, Capa-Mora ED, Prohens J, Alejandro JD, Acosta-Quezada PG (2017) The impact of an extreme climatic disturbance and different fertilization treatments on plant development, phenology, and yield of two cultivar groups of Solanum betaceum Cav. PLoS ONE 12: e0190316.

Widrlechner MP, Daly C, Keller M, Kaplan K (2012) Horticultural applications of a newly revised USDA Plant Hardiness Zone Map. Hort Technology 22: 6-19.

Wulff RD (1987) Effects of irradiance, temperature, and water status on growth and photosynthetic capacity of Hyptis suaveolens. Can J Botany 65: 2501-2506.

Zhang X, Wei H, Zhao Z, Liu J, Zhang Q, Zhang X, Gu, W (2020) The Global Potential Distribution of Invasive Plants: Anredera cordifolia under Climate Change and Human Activity Based on Random Forest Models. Sustainability 12: 1491. 